報文

\title{
亜硝酸イオンのザルツマン法による比色分析における 試薬濃度と反応速度の影響
}

井上 友昭 ${ }^{1}$

\begin{abstract}
アゾ色素へ誘導する亜硝酸イオンの比色分析において，スルファニル酸又はスルファニルアミドと $N-(1-$ ナフチル)エチレンジアミンの混合割合の本分析への影響及び本分析で起きているジアゾ化とカップリング 反応を速度論的に検討し，これらを基に本分析への影響について考察した．本分析に広く用いられているザ ルツマン試薬〔スルファニル酸と $N$-(1-ナフチル)エチレンジアミンのリン酸酸性溶液〕を用いるよりもこれ らの成分試薬を段階的に順次に加える方法の方が感度は $23 \%$ 向上し，また，スルファニル酸の代わりにス ルファニルアミドを用いて段階的に加える方法では $41 \%$ 向上する. 一方, リン酸酸性下に扔ける反応速度 はジアゾ化，カップリング反応共に二次反応であり，反応速度を $R$, 速度定数を $k$, 各モル濃度を [ ] で表 すと, 速度式は順に $R=k$ [スルファニル酸又はスルファニルアミド][亜硝酸イオン],$R=k[$ [ジアゾニウム 塩][N-(1-ナフチル)エチレンジアミン] で表される．また，カップリング反応はジアゾ化よりも約 10 倍速い.
\end{abstract}

\section{1 はじめに}

亜硝酸イオンの比色分析には Griess-Romijn 法 ${ }^{1)}$ (スルフ アニル酸・ $\alpha$-ナフチルアミン・酒石酸又は酢酸系), ザル ッマン 法 ${ }^{2)}$ 〔スルファニル酸・N-(1-ナフチル)エチレンジ アミン (以後 NEDA と略記する)・リン酸又は酶酸系了及 びヤコブス・ホッカイザー法 ${ }^{3}$ （スルファニルアミド・

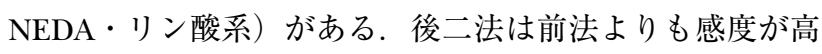
いとされている．これらの研究は $1940 １ 950$ 年代に活発 になされ，以来広く環境測定などへ応用されてきた。 しか し, 後二法そのものについての報告例, 特に反応速度定数 に関する報告例は見ない，昨今, 高校や大学での環境教育 の一つとしてあるいは市民による環境調查として, ザルッ マン法による大気中の二酸化窒素の測定は盛んに実施され ている. 重宝されている理由は何と言ってもその簡便さで あると思われる. 本比色分析は最も多く実施されている分 析の一つであろう。本法への理解を深め, また，より適し た条件及び方法の確認を目指して本研究をスタートした。 その結果, ザルッマン法では, 試料中の亜硝酸イオンの約 20\% が NEDA と反応していることを見いだした"4).ザルッ マン試薬のように混合溶液を用いる限りこの点を避けるこ とはできない. ジアゾ化で完全に亜硝酸イオンが消費され た後に NEDAを加えることによりこの問題は解決され $ろ^{6}$. その方法が後述の「別添法」(図中では stepwise method としてある) である.

${ }^{1}$ 日本大学工学部総合教育 : 963-8642 福島県郡山市田村町徳定 字中河原 1
本報告では，(1) ザルッマン試薬の構成成分であるスル ファニル酸と NEDA・二塩酸塩の混合割合によるアゾ色素 の生成量への影響, (2) 前述の混合溶液を試料へ加える混 合法（四中では mixing method としてある）と，試料へま ずスルファニル酸溶液を加え，ジアゾ化を終了させた後に NEDA 溶液を加えてカップリングさせる別添法とのアゾ色 素の生成量の比較, (3) スルファニル酸のジアゾ化及びジ アゾニウム塩のカップリング反応の反応速度, (4) スルフ アニル酸の代わりにスルファニルアミドを用いた場合の上 述の (1)～(3)の結果を示す。な押，溶媒はリン酸酸性と酢 酸酸性についてである，反応速度定数の報告は本報が初め てであるが，反応機構を解明することが目的ではなく，分 析に必要な反応時間を知るためである．以上を総合的に判 断して, 分析条件について考察する.

\section{2 実験方法}

\section{$2 \cdot 1$ 試薬, 溶液及び機器}

試薬：スルファニル酸，スルファニルアミド，NEDA · 二塩酸塩, リン酸及び酢酸は市販の特級品をそのまま使用 した．亜硝酸ナトリウムは特級品を $105 \sim 110^{\circ} \mathrm{C}$ で数時間 乾燥したものを使用した。

亜硝酸ナトリウム原液及び標準液：亜硝酸ナトリウム

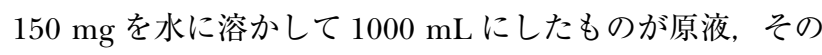
$10 \mathrm{~mL}$ を更に $100 \mathrm{~mL}$ へ希釈したものが標準液である。し たがって, 原液は $2.20 \times 10^{-3} \mathrm{~mol} / \mathrm{L}$, 標準液は $2.20 \times 10^{-4}$ $\mathrm{mol} / \mathrm{L}$ である.

スルファニル酸・リン酸及びスルファニルアミド・リン 
Table 1 Conditions for diazotization rate

\begin{tabular}{|c|c|c|c|c|}
\hline \multirow{2}{*}{$\begin{array}{l}\text { Soln. of sulfanilic } \\
\text { acid or sulfanilamide }\end{array}$} & \multirow{2}{*}{ Water } & \multirow{2}{*}{$\begin{array}{l}\text { Original soln. of } \\
\mathrm{NaNO}_{2}\end{array}$} & \multicolumn{2}{|c|}{ Initial concentration in reaction soln. } \\
\hline & & & sulfanilic acid or sulfanilamide & $\mathrm{NaNO}_{2}$ \\
\hline $4 \mathrm{~mL}$ & $2 \mathrm{~mL}$ & $1 \mathrm{~mL}$ & $3.30 \times 10^{-5} \mathrm{~mol} \mathrm{~L}^{-1}$ & $3.14 \times 10^{-4} \mathrm{~mol} \mathrm{~L}^{-1}$ \\
\hline 4 & 1 & 2 & $3.30 \times 10^{-5}$ & $6.27 \times 10^{-4}$ \\
\hline 4 & 0 & 3 & $3.30 \times 10^{-5}$ & $9.41 \times 10^{-4}$ \\
\hline
\end{tabular}

Table 2 Conditions for coupling reaction rate

\begin{tabular}{ccccc}
\hline $\begin{array}{c}\text { Soln. of sulfanilic } \\
\text { acid or sulfanilamide }\end{array}$ & $\begin{array}{c}\text { St. soln. of } \\
\mathrm{NaNO}_{2}\end{array}$ & $\begin{array}{c}\text { Soln. of } \\
\text { NEDA }\end{array}$ & \multicolumn{2}{c}{ Initial concentration in reaction solution } \\
\cline { 4 - 5 } & $2 \mathrm{~mL}$ & $9 \mathrm{~mL}^{\mathrm{a})}$ & $2.20 \times 10^{-5} \mathrm{~mol} \mathrm{~L}^{-1}$ & $1.09 \times 10^{-4} \mathrm{~mol} \mathrm{~L}^{-1}$ \\
9 & 2 & $9^{\text {b) }}$ & $2.20 \times 10^{-5}$ & $1.79 \times 10^{-4}$ \\
9 & 2 & $9^{\text {c) }}$ & $2.20 \times 10^{-5}$ & $2.75 \times 10^{-4}$ \\
\hline
\end{tabular}

a) $2.43 \times 10^{-4} \mathrm{~mol} \mathrm{~L}^{-1}$; b) $3.98 \times 10^{-4} \mathrm{~mol} \mathrm{~L}^{-1}$; c) $6.10 \times 10^{-4} \mathrm{~mol} \mathrm{~L}^{-1}$

酸: スルファニル酸又はスルファニルアミド $0.01 \sim 1 \mathrm{~g}$ の それぞれへ濃リン酸 $3 \mathrm{~mL}$ を加え, 水で $100 \mathrm{~mL}$ にした. 濃 度は約 $5.8 \times 10^{-4} \sim 5.8 \times 10^{-2} \mathrm{~mol} / \mathrm{L}$ ，なおリン酸は 0.44 $\mathrm{mol} / \mathrm{L}$ である.

NEDA・リン酸 : NEDA・二塩酸塩 5 〜0 mgのそれぞ れへ濃リン酸 $3 \mathrm{~mL}$ を加え, 水で $100 \mathrm{~mL}$ にした。 これら は $1.9 \times 10^{-4} \sim 1.5 \times 10^{-3} \mathrm{~mol} / \mathrm{L}$ である.

各酢酸酸性溶液: 上記各溶液の濃リン酸の代わりに, 水 酢酸 $5 \mathrm{~mL}$ を使用し，同様に調製した。酢酸の濃度は 0.87 $\mathrm{mol} / \mathrm{L}$ である.

機器 : 島津紫外可視分光光度計 UV-1700を用いて吸光度 を測定した。

\section{$2 \cdot 2$ 試薬濃度の影響}

[混合法]: 各濃度のスルファニル酸溶液又はスルファ ニルアミド溶液 $9 \mathrm{~mL}$ と NEDA 溶液 $9 \mathrm{~mL}$ を混合後, 亜硝 酸ナトリウム標準液 $2 \mathrm{~mL}$ を加える. すなわちザルッマン 法と同じ方法である.

[別添法]：スルファニル酸又はスルファニルアミドの 各溶液 $9 \mathrm{~mL}$ へ亜硝酸ナトリウム標準液 $2 \mathrm{~mL}$ を加え, 5 分 間放置する.その後に NEDA 溶液 $9 \mathrm{~mL}$ を加える.

混合法では亜硝酸ナトリウムを加えてから, 別添法では NEDA を加えてから約 60 分間アゾ色素の吸収極大付近で ある $540 \mathrm{~nm}$ での吸光度 $A b_{540}$ を追跡した. 溶液の組成と 15 分後の $A b_{540}$ との関係を用いて考察した. なお, 反応温度 は $20.0^{\circ} \mathrm{C}$ である。

\section{$2 \cdot 3$ ジアゾ化及びカップリング反応の反応速度の測定}

ジアゾ化：各溶液は恒温槽で, 各測定器具は室温を調節 することにより所定温度にした. 恒温槽に浸してある $100 \mathrm{~mL}$ 試験管へ Table 1 に示したスルファニル酸溶液又はスルフ
アニルアミド溶液と水をとり，混合した。そこへ亜硝酸ナ トリウム原液をマイクロピペットで必要量加えた．急い で, 擋拌混合後, 分光光度計へセットしてあるセルへ反応 溶液を移し， $270 \mathrm{~nm}$ での吸光度 $A b_{270}$ を追跡した.この間 速くても40 秒かかった. 分光光度計へは前もって恒温槽 の水を循環し, セルと共に所定温度にしておいた，測定温 度は 5〜30 Cである.

カップリング反応：温度制御に関しては上述のジアゾ 化と同じである. $20^{\circ} \mathrm{C}$ の恒温槽に浸してある $100 \mathrm{~mL}$ 試験 管へ Table 2 のスルファニル酸溶液又はスルファニルアミ ド溶液と亜硝酸ナトリウム標準液をとり, 混合後恒温槽に 5 分間放置した. ここでジアゾ化を終了させる. その後 10 分間カップリング反応測定用の恒温槽へ浸した。 そこへ同 恒温槽に浸してある各濃度の NEDA 溶液をマイクロピペ ットで加え, 混合後, 急いで反応溶液を分光光度計のセル へ移し, $540 \mathrm{~nm}$ での吸光度 $A b_{540}$ を追跡した. 測定温度は 2〜20ㄷ である.

\section{3 結果と考察}

\section{$3 \cdot 1 \quad$ 混合法と別添法における試薬濃度の影響 ${ }^{4)}$}

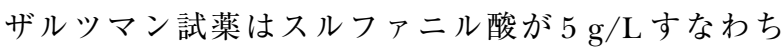
$2.89 \times 10^{-2} \mathrm{~mol} / \mathrm{L}, \quad \mathrm{NEDA}$ ・二塩酸塩が $0.050 \mathrm{~g} / \mathrm{L}$ すなわ ち $1.93 \times 10^{-4} \mathrm{~mol} / \mathrm{L}$ の $0.44 \mathrm{~mol} / \mathrm{L}$ リン酸酸性の混合水溶 液である.

まず反応溶液中の NEDA・二塩酸塩濃度を $0.047 \mathrm{~g} / \mathrm{L}=$ $1.8 \times 10^{-4} \mathrm{~mol} / \mathrm{L}$ の一定, すなわち, カップリングの条件 を一定にして, ジアゾ化時のスルファニル酸又はスルファ ニルアミドの濃度を変化させたときの 15 分後の $A b_{540}$ への 影響を検討した

Fig. 1 に示したように, 混合法においては, 眓中の A, $\mathrm{C}, \mathrm{E}$ のようにスルファニル酸又はスルファニルアミドの 


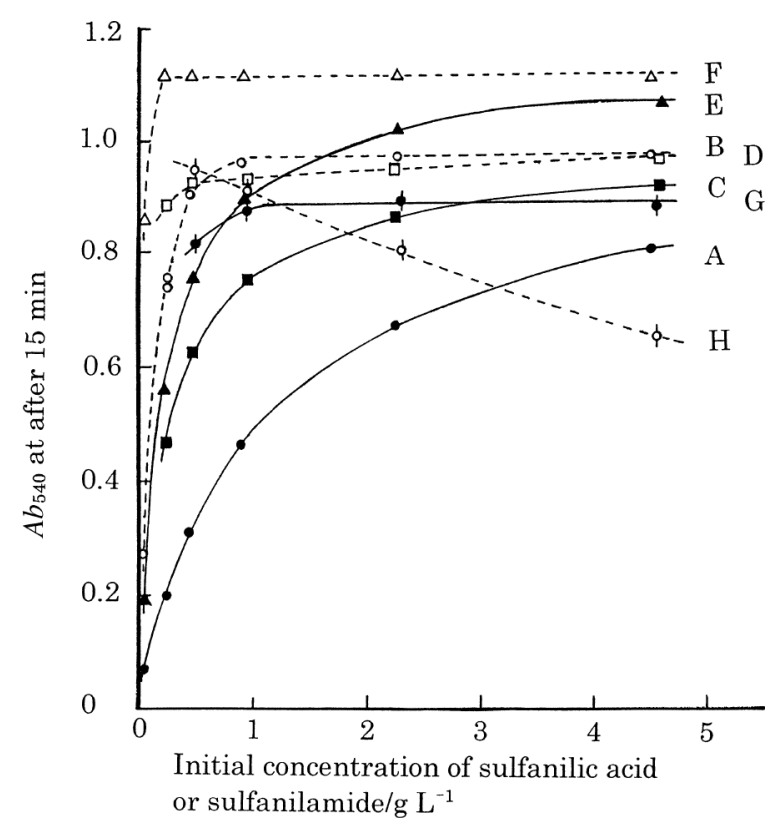

Fig. 1 Relation between the initial concentration of sulfanilic acid or sulfanilamide and the absorbance at $540 \mathrm{~nm}$ at after $15 \mathrm{~min}$

Concentration of NEDA $\cdot 2 \mathrm{HCl}: 0.047 \mathrm{~g} \mathrm{~L}^{-1} ; \mathrm{A} \sim \mathrm{H}$ :

sulfanilic acid

sulfanilamide

\begin{tabular}{ccccc}
\hline & $\begin{array}{c}\text { phosphoric } \\
\text { acid }\end{array}$ & acetic acid & $\begin{array}{c}\text { phosphoric } \\
\text { acid }\end{array}$ & acetic acid \\
\hline $\begin{array}{c}\text { mixing } \\
\text { method } \\
\text { stepwise } \\
\text { method }\end{array}$ & A & C & E & G \\
\hline
\end{tabular}

濃度が濃いほど高い $A b_{540}$ を示している.すなわち，アゾ 色素の生成量が多いことを示している，次に，別添法にお

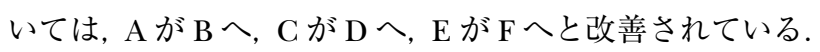
ただし，スルファニルアミド・䣷酸では $\mathrm{G}$ が $\mathrm{H}$ へと高濃 度側で逆に悪化している．H はスルファニルアミド自身が ジアゾ化時に負の作用をしていることを示している.

ザルッマン試薬に該当する Fig. 10右端の点で比較する と, B は A より $23 \%$ 大きく, F は A より $41 \%$ 大きい. ま た， B ではスルファニル酸が $1 \mathrm{~g} / \mathrm{L}$ 以上で，Dでは同じく $0.5 \mathrm{~g} / \mathrm{L}$ 以上で, Fではスルファニルアミドが $0.2 \mathrm{~g} / \mathrm{L}$ 以上 でそれぞれに最高の一定值を示した。

次に, スルファニル酸又はスルファニルアミド濃度を $4.5 \mathrm{~g} / \mathrm{L}=2.6 \times 10^{-2} \mathrm{~mol} / \mathrm{L}$ の一定, すなわち, ジアゾ化の 条件を一定にして, NEDA・二塩酸塩濃度を変化させたと きの 15 分後の $A b_{540}$ への影響を調べた. Fig. 2 に結果を示 したように，混合法である図中の A, G, E はいずれも NEDAの濃度が濃いほどアゾ色素の生成量は少ないことを 示している. 別添法である B, D, Fでは $0.025 \mathrm{~g} / \mathrm{L}$ 以上の $\mathrm{NEDA}$ ・二塩酸塩で最高の一定值を示した。

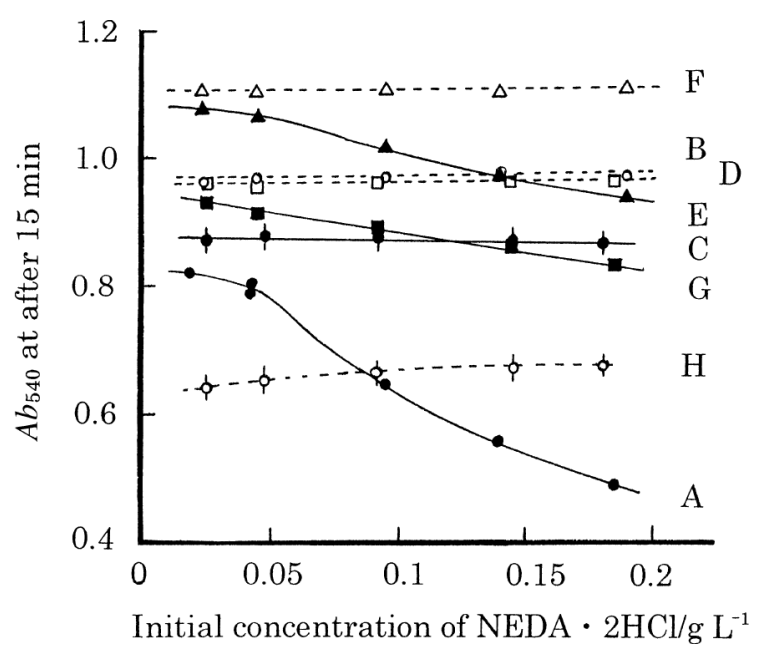

Fig. 2 Relation between the initial concentration of NEDA and the absorbance at $540 \mathrm{~nm}$ at after $15 \mathrm{~min}$ Concentration of sulfanilic acid or sulfanilamide : 4.5 $\mathrm{g} \mathrm{L}^{-1} ; \mathrm{A} \sim \mathrm{H}$ : same as Fig. 1 .

Saltzman は混合法における NEDA 濃度が濃いほど副反 応が多く起こり，アゾ色素による吸光度が減ることを述べ ている ${ }^{2)}$. 本報の Fig. 2 も同じ結果であり, 副反応とは恐 らく反応溶液中の亜硝酸が NEDAのアミンやイミンと反 応してニトロソ化合物を生成する反応であろうと思われ る.すなわち, スルファニル酸と NEDA が亜硝酸を奪い合 っていることになる. Fig. 1 における「スルファニル酸又 はスルファニルアミドの濃度は濃いほどよい」結果は, こ れらの濃度が濃くなるほどこれらと反応する亜硝酸が多く なりアゾ色素が多く生成するためと考えられる，逆に NEDA の濃度が濃くなると副反応が増え, アゾ色素の生成 量は減少することになる. なお, 別添法においてスルファ ニル酸とNEDAの添加順を入れ換え, すなわち, 先に NEDA を加え, その後にスルファニル酸を加えると少量の アゾ色素が生成するのみであることからも NEDA と亜硝 酸が反応していることは明らかである．なお，Fig. 2 の C すなわちスルファニル酸・酢酸系の混合法では NEDA 濃 度の影響をほとんど受けていない. 理由は不明である.

Fig. 1，29別添法で示されている平らな部分において は, ジアゾ化，カップリング反応共に $100 \%$ 進行した結果 であると考えられる. 例えば F の場合, Fig. 1 よりスルフ アニルアミドの濃度は $0.25 〜 4.5 \mathrm{~g} / \mathrm{L}$ と 20 倍にわたる濃度 範囲であり, Fig. 2 からは $0.025 〜 0.190 \mathrm{~g} / \mathrm{L}$ と 8 倍にわた る NEDA の濃度範囲であるにもかかわらず一定值である ことは両反応が共に $100 \%$ 進行したと考えることが自然で あろう．これらの平らな部分での吸光度を用いてアゾ色素 のモル吸光係数を求めると, $\mathrm{B}, \mathrm{D}$ よりスルファニル酸から の場合で 44600, Fよりスルファニルアミドの場合で51000 であった. なおグリース-ロミイン（GR）試薬によるアゾ色 


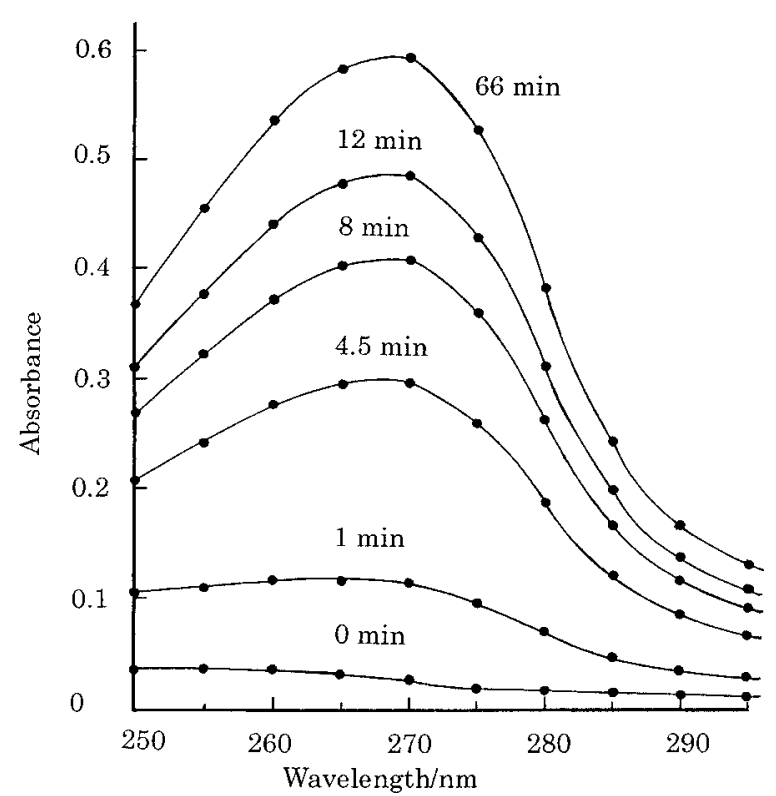

Fig. 3 Spectrum change on diazotization of sulfanilic acid at $20.0^{\circ} \mathrm{C}$

Initial concentrations ; sulfanilic acid : $3.31 \times 10^{-5} \mathrm{M}$, sodium nitrite : $9.32 \times 10^{-4} \mathrm{M}$

素の $530 \mathrm{~nm}$ でのモル吸光係数は 46000 と報告されている7 ${ }^{7)}$.

Fig. 1 の右端の各点（ザルツマン試薬と同濃度）におけ る $\mathrm{A}, \mathrm{C}, \mathrm{E}$ はそれぞれ B, D, Fの 18.6，4.9，4.3\% 小さ な值である。これらの值は試料中の亜硝酸イオンが副反応 を起こした割合になる.

なお，スルファニル酸が $0.5 \mathrm{~g} / \mathrm{L}$ 以下では濃度が小さく なるにつれて $A b_{540}$ も小さくなっている. これらではスル ファニル酸の濃度が小さいためにジアゾ化が十分進行しな かったのではないかと思われる.

分析にとり最も感度のよい方法はスルファニルアミド・ リン酸系の別添法で, その濃度はスルファニルアミドが $0.25 \mathrm{~g} / \mathrm{L}$ 以上, NEDA・二塩酸塩が $0.025 \mathrm{~g} / \mathrm{L}$ 以上になる. 二番目に適しているものは同系の混合法で, その濃度は順 に $4.5 \mathrm{~g} / \mathrm{L}, 0.020 \mathrm{~g} / \mathrm{L}$ である. スルファニル酸を用いる場 合は，別添法であればリン酸系又は酢酸系でよいが，混合 法であれば酢酸系の方がよい. なお，スルファニルアミ ド・酢酸系は混合法の方が別添法よりもよいが, スルファ ニルアミドと NEDA・二塩酸塩に低濃度を用いるなどの注 意が必要である.

JIS 法（JIS K 0102）には, 本報でいう別添法と混合法が 示されている ${ }^{8)}$. JIS の別添法は $0.30 \sim 0.33 \mathrm{~mol} / \mathrm{L}$ 塩酸酸 性の条件であるので, 本法と直接比較はできない. しかし, JIS の混合法は本報の条件域に入っており, すなわち, Fig. 1 中の $\mathrm{E}$ の横軸 0.8 の点に該当する.この点では $20 \%$ の亜硝 酸イオンが副反応を起こす条件である. したがって, JIS 法 の発色試薬（本報のヤホ試薬）のスルファニルアミドを現

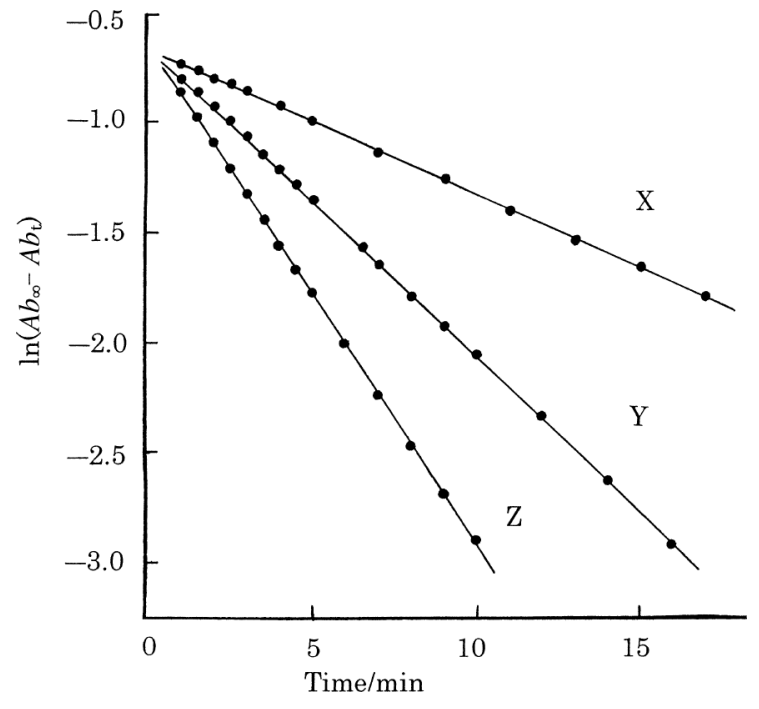

Fig. 4 First order reaction plots of diazotization in sulfanilic acid $\cdot$ phosphoric acid at $20.0^{\circ} \mathrm{C}$

Concentrations of nitrite ; X : $3.14 \times 10^{-4} \mathrm{~mol} \mathrm{~L}^{-1}, \mathrm{Y}$ : $6.27 \times 10^{-4} \mathrm{~mol} \mathrm{~L}^{-1}, \mathrm{Z}: 9.41 \times 10^{-4} \mathrm{~mol} \mathrm{~L}^{-1}$

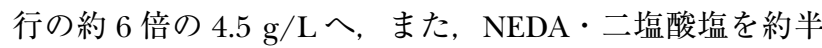
分の $20 \mathrm{mg} / \mathrm{L}$ への変更を勧めたい. この変更により副反応 を数\%に抑えることができる.

\section{$3 \cdot 2$ ジアゾ化及びカップリング反応速度 ${ }^{5}$}

ジアゾ化とカップリング反応の反応速度の測定であるか ら, $2 \cdot 3$ で述べたように, 方法としては別添法に該当する. スルファニル酸・NEDAのリン酸系と酢酸系及びスルファ ニルアミド・NEDAのリン酸系の三つの系についてジアゾ 化とカップリング反応の反応速度を測定した．スルファニ ル酸・NEDA・リン酸系について詳しく述べ，他は結果の みを主に示す。

ジアゾ化：Table 1 は亜硝酸ナトリウム（反応溶液中で は亜硝酸の状態で存在している）が過剩に存在する条件で あり, その条件下での UV 吸収スペクトル変化を Fig. 3 に 示した. 本図より $A b_{270}$ の経時変化でジアゾ化を追跡でき ることが分かる. 各 $A b_{270}$ からスルファニル酸自身の吸光 度（時間と共に減少する）と亜硝酸自身の吸光度（実質的 に一定）を差し引いて補正した. 補正後の $A b_{270}$ を 1 次反 応プロットしたものが Fig. 4 である. Fig. 4 の直線の勾配 が $k_{\mathrm{obs}}$ である. すなわち， ジアゾ化反応速度 $R$ は $R=k_{\mathrm{obs}}$ [スルファニル酸］と表される. 更に, $k_{\mathrm{obs}}$ と車硝酸イオン 濃度との関係を示したものが Fig. 5 であり，本図より $k_{\mathrm{obs}}$ $=k\left[\mathrm{NO}_{2}{ }^{-}\right]$と表される. 以上から, $R=k\left[\mathrm{NO}_{2}{ }^{-}\right][$スルフ アニル酸］となる，ただし，一定濃度のリン酸下又は酢酸 下という条件が付く. Table 3 に各温度の速度定数及び他 の速度論的定数を示した. 一方, Fig. 6 にはアレニウスプ ロットしたものを示した。 なお, 過塩素酸下でのアニリン 
のジアゾ化について Hughes 等 ${ }^{9)}$ は本報とは明らかに異な

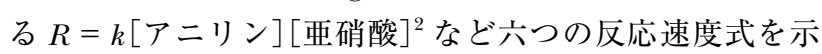
している，本報と彼らとでは酸の種類が異なり，また，反 応速度も本報より桁違いに遅いことなどから比較検討はで きない.

カップリング反応 : Table 2 は NEDA が過剩に存在する 条件であり, 本反応系で有色の物質はアゾ色素のみである ので, $A b_{540}$ で反応を追跡し, 補正することなくデー夕処理 した. $A b_{540}$ の 1 次反応プロットは直線となり, その勾配の

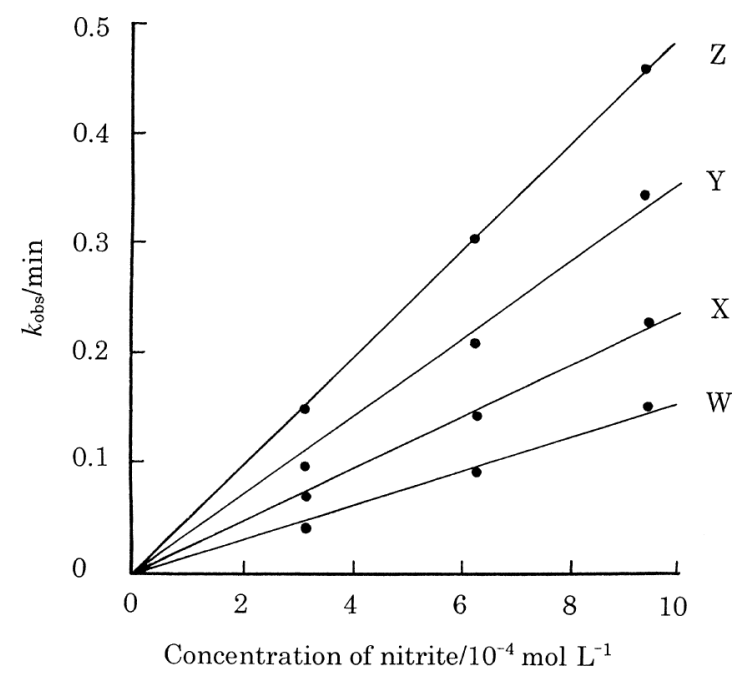

Fig. 5 Relation between $k_{\text {obs }}$ of diazotization and the concentration of nitrite in sulfanilic acid $\cdot$ phosphoric scid

Temp. $/{ }^{\circ} \mathrm{C} ; \mathrm{W}: 15.0, \mathrm{X}: 20.0, \mathrm{Y}: 25.0, \mathrm{Z}: 30.0$ $k_{\mathrm{obs}}$ は NEDA 濃度に比例したので，カップリング反応速度

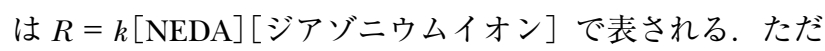
し, ジアゾ化と同様酸濃度一定の条件が付く. 各温度の速 度定数及び速度論的定数を Table 3 に, アレニウスプロッ トを Fig. 6 に示した。

速度論的考察：スルファニルアミド・酢酸系のカップ リング反応を除いて, Table 3 より, $20^{\circ} \mathrm{C}$ で比較してみる とカップリング反応はジアゾ化よりも約 10～ 20 倍速いこ とが分かる。

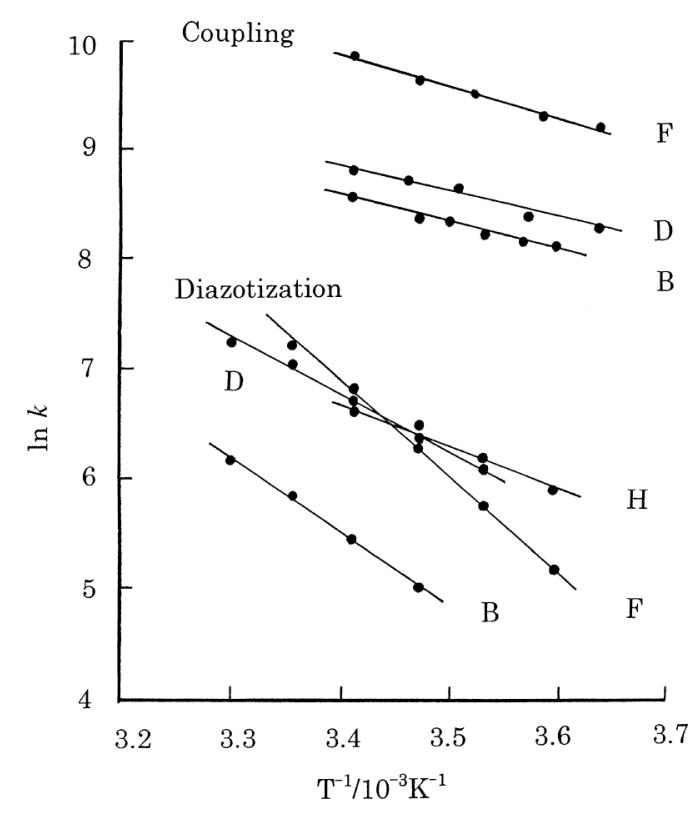

Fig. 6 Arrhenius plot of diazotization and coupling $\mathrm{B} \sim \mathrm{H}:$ same as Fig. 1 .

Table 3 Kinetics constants

\begin{tabular}{|c|c|c|c|c|c|c|c|}
\hline \multicolumn{4}{|c|}{ Sulfanilic acid } & \multicolumn{4}{|c|}{ Sulfanilamide } \\
\hline \multicolumn{2}{|c|}{ Phosphoric acid } & \multicolumn{2}{|c|}{ Acetic acid } & \multicolumn{2}{|c|}{ Phosphoric acid } & \multicolumn{2}{|c|}{ Acetic acid } \\
\hline$t /{ }^{\circ} \mathrm{C}$ & $k$ & $t /{ }^{\circ} \mathrm{C}$ & $k$ & $t /{ }^{\circ} \mathrm{C}$ & $k$ & $t /{ }^{\circ} \mathrm{C}$ & $k$ \\
\hline \multicolumn{8}{|c|}{ Diazotization } \\
\hline 15.0 & 150 & 10.0 & 441 & 4.9 & 174 & 5.0 & 365 \\
\hline 20.0 & 233 & 15.0 & 581 & 10.0 & 315 & 10.1 & 489 \\
\hline 25.0 & 345 & 20.0 & 816 & 15.0 & 529 & 15.0 & 649 \\
\hline \multirow[t]{2}{*}{30.0} & 485 & 25.0 & 1150 & 20.0 & 900 & 20.0 & 750 \\
\hline & & 30.0 & 1402 & 25.0 & 1367 & & \\
\hline$\Delta H^{\dagger}$ & 12.9 & & 9.1 & & 15.8 & & 6.6 \\
\hline$\Delta S^{\dagger}$ & -12 & & -22 & & 0.9 & & -31 \\
\hline \multicolumn{8}{|c|}{ Coupling reaction } \\
\hline 5.0 & 3336 & 1.9 & 3900 & 1.9 & 9650 & 20.0 & 0.0184 \\
\hline 7.3 & 3436 & 6.9 & 4336 & 5.9 & 10900 & 25.0 & 0.0309 \\
\hline 10.0 & 3712 & 12.0 & 5647 & 10.8 & 13620 & 30.0 & 0.0534 \\
\hline 12.7 & 4200 & 15.9 & 6100 & 15.0 & 15250 & & \\
\hline 15.0 & 4284 & 20.0 & 6633 & 20.0 & 19200 & & \\
\hline 20.0 & 5200 & & & & & & \\
\hline$\Delta H^{\dagger}$ & 4.1 & & 3.6 & & 4.8 & & 18.3 \\
\hline$\Delta S^{\dagger}$ & -36 & & -37 & & -31 & & -12 \\
\hline
\end{tabular}

Units of $\Delta H^{\dagger}, \Delta S^{\dagger}$ and $k$ are kcal mol${ }^{-1}$, eu. and $\mathrm{L} \mathrm{mol}^{-1} \mathrm{~min}^{-1}$ 


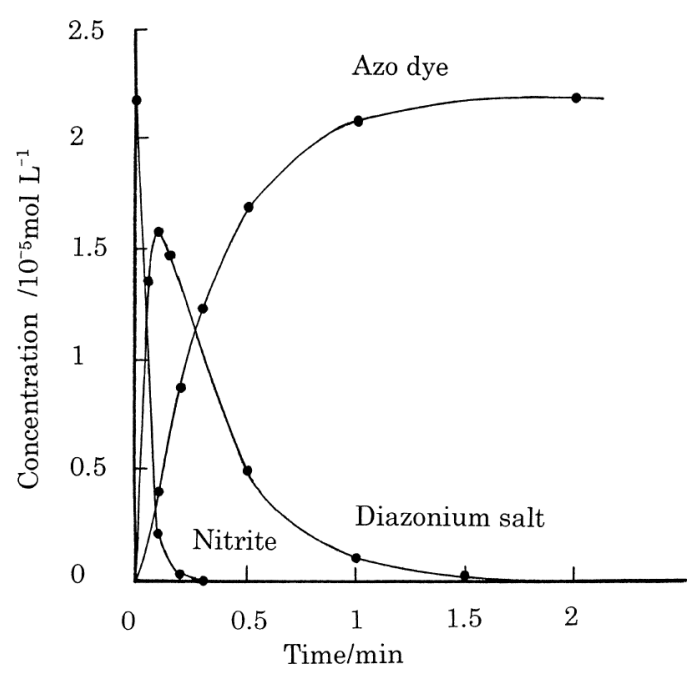

Fig. 7 Time-course of concentrations on mixing method in sulfanilamide $\cdot$ phosphoric acid at $20.0^{\circ} \mathrm{C}$ Initial concentrations ; sulfanilamide : $4.5 \mathrm{~g} \mathrm{~L}^{-1}=$ $2.62 \times 10^{-2} \mathrm{~mol} \mathrm{~L}^{-1}$, NEDA : $0.0446 \mathrm{~g} \mathrm{~L}^{-1}=1.72 \times$ $10^{-4} \mathrm{~mol} \mathrm{~L}^{-1}$, nitrite : $2.17 \times 10^{-5} \mathrm{~mol} \mathrm{~L}^{-1}$

ジアゾ化速度のみを比較してみると，スルファニル酸・ リン酸系が最も遅く, 他の三系では $3 \sim 4$ 倍速い.リン酸 使用のザルッマン試薬の場合, 亜硝酸イオンの $18.6 \%$ が NEDA と反応し, 一方, リン酸使用のスルファニルアミド の混合法 (Fig. 1 中の E) の場合, ザルッマン法と同濃度 に扔いて亜硝酸イオンの $4.3 \%$ が NEDA と反応しているこ とを前述した．スルファニルアミドはスルファニル酸より も 3.9 倍速く亜硝酸と反応するので, NEDA と反応する亜 硝酸の量が減ることは容易に理解できる. 18.6/3.86= $4.8 \%$ は上の $4.3 \%$ とほぼ一致することもその裏づけであ ろう.

一方，カップリング反応は，スルファニルアミド・酢酸

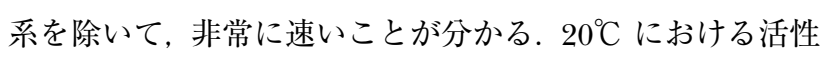
化エンタルピー $\Delta H^{\dagger}$ が $4 \sim 5 \mathrm{kcal} / \mathrm{mol}$ と小さく, 活性化エ ントロピー $\Delta S^{\dagger} も-30 \sim-40 \mathrm{eu}$ と小さいので, ジアゾニ ウムイオンと NEDA が直接反応し, 両者が結合したような 活性錯合体を経由してアゾ色素を生成しているものと思わ れる。

混合法では，ジアゾ化とカップリング反応が同時並行的 に進行し, 各濃度変化は次式で表される ${ }^{10)}$.

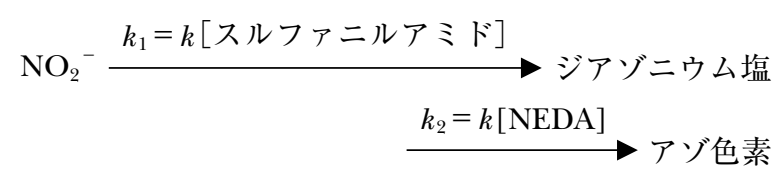

$\left[\mathrm{NO}_{2}{ }^{-}\right]=\left[\mathrm{NO}_{2}^{-}\right]_{0} \mathrm{e}^{-k_{1} t}$

$[$ ジアゾニウム塩 $]=\left\{k_{1} /\left(k_{1}-k_{2}\right)\right\}\left[\mathrm{NO}_{2}^{-}\right]_{0}\left(\mathrm{e}^{-k_{2} t}-\mathrm{e}^{-k_{1} t}\right)$

[アゾ色素 $]=\left[\mathrm{NO}_{2}^{-}\right]_{0}\left[1+\left\{k_{2} /\left(k_{1}-k_{2}\right)\right\} \mathrm{e}^{-k_{1} t}\right.$

$$
\left.-\left\{k_{1} /\left(k_{1}-k_{2}\right)\right\} \mathrm{e}^{-k_{2} t}\right]
$$

Table 3 に示した $20^{\circ} \mathrm{C}$ の值を用いて算出した各濃度の変 化の例を Fig. 7 に示す. 本図の条件では，ジアゾ化は 0.3 分でほぼ終了し, カップリング反応も 1.5 分後には終了し ている. JISの混合法におけるスルファニルアミドと NEDA の濃度を用いて同様に算出すると, $20^{\circ} \mathrm{C}$ での亜硝酸イオ ンの半減期は 9.6 秒, 一方, アゾ色素の $50 \%$ 生成期間は 29.4 秒となる. 294 秒（約 5 分間）で $99.9 \%$ のアゾ色素が 生成する. したがって, 現行の JIS 法における反応のため の放置時間 20 分は 10 分間で十分と考えられる.

ところで，スルファニルアミド・酢酸系に扔けるカップ リング反応は他の三者よりも速度にして $10^{-5} \sim 10^{-6}$ 倍で, 明らかに反応機構が異なるものと思われる.酢酸酸性下で のアニリンのジアゾ化は, 次に示したようにジアゾニムイ オンが未反応のアニリンと反応し，ジアゾアミン類を生成

$$
\begin{aligned}
\text { (0) }-\mathrm{NH}_{2} \longrightarrow & \text { (O) }-\mathrm{N}_{2}{ }^{+} \longrightarrow \\
& \longrightarrow \text { (O) }-\mathrm{N}_{2}-\mathrm{NH}-(\mathrm{O}\rangle \\
& \longrightarrow \text { (O) }-\mathrm{N}_{2}-\text { (O) }-\mathrm{NH}_{2}
\end{aligned}
$$

し, 続いて転移して最終的にはアゾ色素を生成する ${ }^{11)}$.

$$
\begin{aligned}
& \mathrm{NH}_{2} \mathrm{SO}_{2}-\mathrm{O}-\mathrm{NH}_{2} \longrightarrow \mathrm{NH}_{2} \mathrm{SO}_{2}-\mathrm{O}^{-} \mathrm{N}_{2}{ }^{+} \\
& \longrightarrow \mathrm{NH}_{2} \mathrm{SO}_{2}-\mathrm{O}-\mathrm{N}_{2}-\mathrm{NH}-\mathrm{O}-\mathrm{SO}_{2} \mathrm{NH}_{2} \\
& \longrightarrow \mathrm{NH}_{2} \mathrm{SO}_{2} \text {-O }-\mathrm{N}_{2} \text { - }
\end{aligned}
$$

スルファニルアミドの場合も上に示した同様な反応が起 きている可能性がある. カップリング反応速度を測定する 前段階のジアゾ化では, スルファニルアミドを過剩に使用 しているので, ジアゾニウムイオンが過剩のスルファニル アミドと反応している可能性は高い，中間体であるジアゾ アミン類が分子間転移で NEDA と反応し, 最終的には同じ アゾ色素を生成しているものと推察される.

\section{4 結 言}

混合法では, ザルッマン試薬のように前もって調製して おくことにより, 試料への試薬添加は 1 回で済む。試薬添 加を 1 回で済ませたいときは, スルファニル酸の場合リン 酸系よりも酶酸系を, スルファニルアミドの場合リン酸系 を用いた方がよい，それぞれの系の最善値の相対的感度は 順に $1: 1.15: 1.35$ である. 一方, 試薬添加が 2 回必要な別 添法ではスルファニル酸のリン酸系及び酶酸系，また， ス ルファニルアミドのリン酸系を锥めたい，相対的感度は順 に $1: 1: 1.15$ である.

ジアゾ化及びカップリング反応がそれぞれ $100 \%$ 進行 し，生成するアゾ色素のモル吸光係数がより大きいスルフ アニルアミド・リン酸系の別添法が分析法としては最善で ある. 一方, 次善はスルファニルアミド・リン酸系の混合 
法である.この場合, 亜硝酸イオンの数\% は NEDA と反応 する。

\section{謝辞}

日本大学工学部学術フロンティア推進事業「中山間地お よび地方都市における環境共生とそれを支える情報通信技 術」(研究代表：小野沢元久)の援助を受けた．記して謝意 を表します。

\section{文献}

1) 日本分析化学会北海道支部編: “水の分析, 第 3 版”, p. 214 (1981), (化学同人).

2) B. E. Saltzman : Anal. Chem., 26, 1949 (1954); Anal. Chem., 32, 135 (1960).

3) M. B. Jacobs, S. Hochheiser : Anal. Chem., 30, 426 (1958).

4) 井上友昭: 第 47 回日本大学工学部学術研究報告会,
講演要旨集, p. 7 (2004) ; 平成 16 年度化学教育研 究協議会東北大会, 講演要旨集, p. 26 (2004).

5) 井上友昭: 第 48 回日本大学工学部学術研究報告会, 講演要旨集, p. 29 (2005) ; 第 49 回日本大学工学部 学術研究報告会, p. 25 (2006) ; 平成 17 年度化学教 育研究協議会東北大会要旨集, p. 61 (2005).

6) B. F. Rider, M. G. Mellon : Anal. Chem., 18, 96 (1946).

7) 新良宏一郎, 庄野利之, 増田 勲訳: “大気污染の 測定”, p. 182 (1973), (化学同人); W. Leithe：“Die Analyse der Luft und ihrer Verunreinigungen in der freien Atmosphäre und am Arbeitsplatz”, (Wissenschaftliche Verlagsgesellschaft mbH.).

8) JIS K 0102, 工場排水試験方法 (2008).

9) E. D. Hughes, C. K. Ingold, J. H. Ridd : J. Chem. Soc., 1958, 58, 65, 70, 77, 82, 88.

10）大岩正芳：“反応速度計算法”, p. 121 (1962), (朝倉 書店).

11) R. B. Wagner, H. D. Zook: “Synthetic Organic Chemistry”, p. 764 (1961), (John Wiley \& Sons Inc).

\title{
Influence of Reagent Concentration and Reaction Rate on Colorimetry of Nitrite Ion by Saltman Method
}

\author{
Tomoaki INOUE ${ }^{1}$ \\ ${ }^{1}$ College of Engineering, Nihon University, 1, Nakagawara, Tokusada, Tamuramachi, Koriyama-shi, Fukushima \\ 963-8642
}

(Received 6 July 2009, Accepted 5 October 2009)

Concerning the colorimetry of nitrite ion induced to azo dye, the influence of the ratio between sulfanilic acid or sulfanilamide and $N$-(1-naphthyl)etylenediamine and the kinetics for the diazotization and coupling reaction are discussed. The sensitivity of a stepwise method is $23 \%$ higher than that using a Saltzmann reagent which is mixture of sulfanilic acid, $N$-(1naphtyl)etylenediamine and phosphoric acid. The same sensitivity is $41 \%$ higher by using sulfanilamide instead of sulfanilic acid. The diazotization and coupling reaction are second-order reaction. That is, $R=k$ [sulfanilic acid or sulfanilamide][nitrite ion] and $R=k$ [diazonium ion] $N$-(1-naphthyl)etylenediamine] respectively. The coupling reaction rate is about 10-times faster than the diazotization.

Keywords : colorimetry ; nitrite ion ; sulfanilamide ; kinetics. 